David Price is a political scientist of whom Hubert Humphrey would be proud, and we are delighted to recognize his achievement.

\section{Carey McWilliams Award ( $\$ 500)$}

Presented each year to honor a major journalistic contribution to our understanding of politics.

Award Committee: John Kingdon, University of Michigan, chair; Hoyt Purvis, University of Arkansas; Robert Putnam, Harvard University.

\section{Recipient: National Journal.}

Citation: The Carey McWilliams Award was established to recognize "a major journalistic contribution to our understanding of politics." This year's recipient is The National Journal. The Journal is known throughout the discipline of political science as an indispensable resource for research and teaching in public policy and in national government and politics. Scholars routinely turn to its pages every time they need case studies of policymaking or background information on various public policies. Professors routinely direct their students to its outstanding coverage as they write dissertations, theses, or term papers. Its Almanac of American Politics is a central sourcebook. Its general coverage of national government and politics instructs students and researchers alike. For all of its contributions to the political science community, The National Journal is an outstanding recipient of the McWilliams Award.

\section{James Madison Award (\$2,000)}

Presented triennially to recognize a career of scholarly excellence rather than a particular piece of scholarship.

Award Committee: Harvey C. Mansfield, Jr., Harvard University, chair; John J. DiIulio, Jr., Princeton University; R.
Shep Melnick, Brandeis University; Catherine Zuckert, Carleton College.

Recipient: James Q. Wilson, University of California, Los Angeles.

Citation: Inspired by James Madison, America's greatest political scientist, James Q. Wilson has shown a lifelong devotion to the study of political behavior. His study has been Madisonian in quality and character. He has never written a book less than excellent; he has enriched the traditional topics beyond measure and led political science into fields where it was hesitant or reluctant to go. His studies are scientifically rigorous in the best sense that gives due weight to necessities, patterns of choice, modes of human character, and happenstance. He has been a teacher to the profession, a profound and prudent adviser to his students, and a treasure to his friends.

\title{
APSA Awards and Recipients
}

\section{Compiled by Jean Walen}

One of the most important activities of the Association is the promotion and recognition of scholarly excellence in political science. Listed below are the recipients of each APSA award who were honored for the high quality of their work and their contributions to the discipline. A cumulative list of the award winners will be published every three years in conjunction with the Madison Award.

* "Affiliation" indicates the recipient's affiliation at the time of receiving the award.

\section{Career Awards}

\section{HUBERT H. HUMPHREY AWARD}

Presented each year in recognition of notable public service by a political scientist.

\begin{tabular}{ll} 
Year & Recipient \\
\hline 1983 & Daniel Patrick Moynihan \\
1984 & John Brademas \\
1985 & Robert C. Wood \\
1986 & - \\
1987 & Max M. Kampelman \\
1988 & Jeane J. Kirkpatrick \\
1989 & Brent Scowcroft \\
1990 & David E. Price
\end{tabular}

Affiliation*

U.S. Senate

New York University

Wesleyan University

David E. Price

Head, U.S. Delegation, Negotiations on Nuclear and Space Arms

Georgetown University

Special Assistant to the President, National Security Affairs

U.S. House of Representatives

\section{JAMES MADISON AWARD}

This award is given to an American political scientist who has made a distinguished scholarly contribution to political science. The award is given triennially.

\begin{tabular}{lll} 
Year & Recipient & Affiliation* $^{*}$ \\
\hline 1978 & Robert A. Dahl & Yale University \\
1981 & Gabriel A. Almond & Stanford University \\
1984 & Herbert Simon & Carnegie-Mellon University \\
1987 & E. Pendleton Herring & President Emeritus, Social Science Research Council \\
1990 & James Q. Wilson & University of California, Los Angeles \\
\hline
\end{tabular}




\section{Gazette}

\section{JOHN GAUS LECTURE}

The John Gaus Distinguished Lecturer is to honor the recipient's lifetime of exemplary scholarship in the joint tradition of political science and public administration and, more generally, to recognize achievement and encourage scholarship in public administration.

Year

Recipient

Affiliation*

1986

Herbert Kaufman

Boston College

1987 C. Dwight Waldo

Maxwell School, Syracuse University

James W. Fesler

1989 Aaron Wildavsky

1990 Frederick C. Mosher (posthumously)

Professor Emeritus, Yale University

University of California, Berkeley

University of Virginia

\section{CHARLES E. MERRIAM AWARD}

This award was given to a person whose published work and career represents a significant contribution to the art of government through the application of social science research.

\begin{tabular}{lll} 
Year & Recipient & Affiliation* \\
\hline 1975 & Aaron Wildavsky & University of California, Berkeley \\
1976 & Alice M. Rivlin & Congressional Budget Office \\
1977 & James Q. Wilson & Harvard University \\
1978 & Don K. Price & Harvard University \\
1979 & E. Pendleton Herring & Social Science Research Council \\
1980 & Evron M. Kirkpatrick & American Political Science Association \\
1981 & Harold F. Gosnell & University of Chicago, Emeritus \\
1982 & Richard E. Neustadt & Harvard University \\
1983 & Jack Peltason & American Council on Education \\
1984 & George F. Kennan & Institute for Advanced Study \\
1985 & James L. Sundquist & Brookings Institution \\
1986 & Thomas Cronin & Colorado College \\
1987 & Richard Nathan & Princeton University \\
\hline
\end{tabular}

\section{CAREY MCWILLIAMS AWARD}

Presented each year to honor a major journalistic contribution to our understanding of politics.

\begin{tabular}{lll} 
Year & Recipient & Affiliation* $^{*}$ \\
\hline 1982 & Richard Strout & Christian Science Monitor \\
1983 & David S. Broder & Washington Post \\
1984 & Murray Kempton & Newsday \\
1985 & Jim Lehrer and Robert MacNeil & MacNeil/Lehrer Newshour \\
1986 & Neal R. Peirce & Washington Post Writers Group \\
1987 & Congressional Quarterly Weekly Report & \\
1988 & Jeffrey H. Birnbaum and Alan S. Murray & Wall Street Journal \\
1989 & Lesley Stahl & CBS News \\
1990 & National Journal & \\
\hline
\end{tabular}

\section{Book Awards}

\section{ATHERTON PRESS PRIZE}

This award was for the best original manuscript in political science.

\begin{tabular}{lll} 
Year & Author & Manuscript \\
\hline 1962 & Dan D. Nimmo & News Sources and News Channels: A Study in Political Communication \\
1962 & Frank J. Sorauf & \begin{tabular}{l} 
Party and Representation \\
\hline
\end{tabular}
\end{tabular}

\section{RALPH J. BUNCHE AWARD}

This award is for the best scholarly work in political science exploring the phenomenon of ethnic and cultural pluralism. Formerly the Ethnic and Cultural Pluralism Award, the award was renamed the Ralph J. Bunche Award by the Council on May 7, 1982.

\begin{tabular}{llll} 
Year & Author & Work & Published by \\
\hline 1978 & Irving Howe & World of Our Fathers & Harcourt, Brace, Jovanovich \\
1979 & Arend Lijphart & Democracy in Plural Societies: A Comparative & Yale University Press \\
& M. Crawford Young & The Politics of Cultural Pluralism & University of Wisconsin Press
\end{tabular}


1980

Mario Barrera

1981 Marguerite Ross Barnett

1982 No award given

1983 John A. Armstrong

Orlando Patterson

1984 Mark Naison

1985 Rufus P. Browning,

Dale Rogers Marshall and

David H. Tabb

1986 Paul R. Dimond

1987 Rasma Karklins

D. Garth Taylor

1988 Earl and Merle Black

1989 Ronald Walters

1990 Clarence N. Stone
Race and Class in the Southwest: A Theory of Racial Inequality

The Politics of Cultural Nationalism in South India

Nations Before Nationalism

Slavery and Social Death: A Comparative Study

Communists in Harlem During the Depression

Protest Is Not Enough: The Struggle of Blacks and Hispanics for Equality in Urban Politics

Beyond Busing: Inside the Challenge to Urban Segregation

Ethnic Relations in the USSR: The Perspective from Below

Public Opinion and Collective Action: The Boston

School Desegregation Conflict

Politics and Society in the South

Black Presidential Politics

Regime Politics: Governing Atlanta, 1946-1988
University of Notre Dame Press

Princeton University Press

University of North Carolina Press

Harvard University Press

University of Illinois Press

University of California Press

University of Michigan Press

Allen \& Unwin

University of Chicago Press

Harvard University Press

State University of New York Press

University Press of Kansas

\section{GLADYS M. KAMMERER AWARD}

This award is for the best political science publication in that year or the previous year in the field of U.S. national policy.

\begin{tabular}{|c|c|c|c|}
\hline Year & Author & Publication & Published by \\
\hline 1971 & Bruce M. Russett & What Price Vigilance? & Yale University Press \\
\hline 1972 & Alice M. Rivlin & Systematic Thinking for Social Action & Brookings Institution \\
\hline 1973 & $\begin{array}{l}\text { Norman N. Nie and } \\
\text { Sidney Verba }\end{array}$ & $\begin{array}{l}\text { Participation in America: Political Democracy and } \\
\text { Social Equality }\end{array}$ & Harper \& Row \\
\hline 1974 & $\begin{array}{l}\text { David P. Calleo and } \\
\text { Benjamin M. Rowland }\end{array}$ & America and the World Political Economy & Indiana University Press \\
\hline 1975 & No award given & & \\
\hline 1976 & $\begin{array}{l}\text { Arnold J. Heidenheimer, } \\
\text { Hugh Heclo, and } \\
\text { Carolyn Teich Adams }\end{array}$ & $\begin{array}{l}\text { Comparative Public Policy: The Politics of Social } \\
\text { Choice in Europe and America }\end{array}$ & St. Martin's Press \\
\hline 1977 & Paul E. Peterson & School Politics Chicago Style & University of Chicago Press \\
\hline 1978 & William Ophuls & Ecology and the Politics of Scarcity & W.H. Freeman \\
\hline 1979 & Edward R. Tufte & Political Control of the Economy & Princeton University Press \\
\hline 1980 & Martha Derthick & Policymaking for Social Security & Brookings Institution \\
\hline 1981 & Gary C. Jacobson & Money in Congressional Elections & Yale University Press \\
\hline & Michael Lipsky & $\begin{array}{l}\text { Street-Level Bureaucracy: Dilemmas of the Individual } \\
\text { in Public Services }\end{array}$ & Russell Sage Foundation \\
\hline 1982 & Elizabeth Sanders & The Regulation of Natural Gas & Temple University Press \\
\hline 1983 & Robert A. Dahl & $\begin{array}{l}\text { Dilemmas of Pluralist Democracy: Autonomy vs. } \\
\text { Control }\end{array}$ & Yale University Press \\
\hline & Mancur Olson & $\begin{array}{l}\text { The Rise and Decline of Nations: Economic Growth, } \\
\text { Stagflation, and Social Rigidities }\end{array}$ & Yale University Press \\
\hline 1984 & $\begin{array}{l}\text { Ithiel de Sola Pool } \\
\text { (posthumously) }\end{array}$ & Technologies of Freedom & Harvard University Press \\
\hline 1985 & $\begin{array}{l}\text { Rufus P. Browning, } \\
\text { Dale Rogers Marshall and } \\
\text { David H. Tabb }\end{array}$ & $\begin{array}{l}\text { Protest Is Not Enough: The Struggle of Blacks and } \\
\text { Hispanics for Equality in Urban Politics }\end{array}$ & University of California Press \\
\hline 1986 & David A. Baldwin & Economic Statecraft & Princeton University Press \\
\hline 1987 & I. M. Destler & American Trade Politics: System Under Stress & $\begin{array}{l}\text { Institute for International } \\
\text { Economics and Twentieth } \\
\text { Century Fund }\end{array}$ \\
\hline & Jane Mansbridge & Why We Lost the ERA & University of Chicago Press \\
\hline 1988 & Dennis F. Thompson & Political Ethics and Public Office & Harvard University Press \\
\hline 1989 & Thomas J. Anton & $\begin{array}{l}\text { American Federalism and Public Policy: How the } \\
\text { System Works }\end{array}$ & $\begin{array}{l}\text { Random House and Temple } \\
\text { University Press }\end{array}$ \\
\hline 1990 & $\begin{array}{l}\text { Donald Alexander Downs } \\
\text { Edward G. Carmines and } \\
\text { James A. Stimson }\end{array}$ & $\begin{array}{l}\text { The New Politics of Pornography } \\
\text { Issue Evolution: Race and the Transformation of } \\
\text { American Politics }\end{array}$ & $\begin{array}{l}\text { University of Chicago Press } \\
\text { Princeton University Press }\end{array}$ \\
\hline
\end{tabular}




\section{BENJAMIN E. LIPPINCOTT AWARD}

This award was given each year for a work of exceptional quality by a living political theorist that is still considered significant after a time span of at least 15 years since the original publication. In 1985 the award was changed to a biennial basis.

\begin{tabular}{lll} 
Year & Author & Work \\
\hline 1975 & Hannah Arendt & The Human Condition \\
1976 & Karl Popper & The Open Society and Its Enemies \\
1977 & Louis Hartz & The Liberal Tradition in America \\
1978 & Eric Voegelin & The New Political Science and Order and History \\
1979 & C. B. Macpherson & The Political Theory of Possessive Individualism \\
1980 & H. L. A. Hart & The Concept of Law \\
1981 & Simone de Beauvoir & The Second Sex \\
1982 & Michael Oakeshott & Experience and Its Modes and two essays, “The \\
& & Voice of Poetry" and his Introduction to Hobbes' \\
1983 & Duncan Black & Leviathan \\
1984 & Sir Isaiah Berlin & The Theory of Committees and Elections \\
1985 & Sheldon Wolin & through 1969 \\
1987 & John Rawls & Politics and Vision \\
1989 & Robert A. Dahl & A Theory of Justice \\
& & A Preface to Democratic Theory \\
\hline
\end{tabular}

\section{VICTORIA SCHUCK AWARD}

This award is for the best book published the previous year on women and politics.

\begin{tabular}{|c|c|c|c|}
\hline Year & Author & Title & Published by \\
\hline 1988 & $\begin{array}{l}\text { Rebecca E. Klatch } \\
\text { Jane Mansbridge }\end{array}$ & $\begin{array}{l}\text { Women of the New Right } \\
\text { Why We Lost the ERA }\end{array}$ & $\begin{array}{l}\text { Temple University Press } \\
\text { University of Chicago Press }\end{array}$ \\
\hline 1989 & Zillah Eisenstein & The Female Body and the Law & $\begin{array}{l}\text { University of California Press, } \\
\text { Berkeley }\end{array}$ \\
\hline 1990 & $\begin{array}{l}\text { Carole Pateman } \\
\text { Susan Moller Okin } \\
\text { Judith Stiehm }\end{array}$ & $\begin{array}{l}\text { The Sexual Contract } \\
\text { Justice, Gender and the Family } \\
\text { Arms and the Enlisted Woman }\end{array}$ & $\begin{array}{l}\text { Stanford University Press } \\
\text { Basic Books } \\
\text { Temple University Press }\end{array}$ \\
\hline
\end{tabular}

\section{WOODROW WILSON FOUNDATION AWARD}

The award is given annually for the best book published on government, politics or international affairs.

\begin{tabular}{cl} 
Year & Name \\
\hline 1947 & Robert M. MacIver \\
1948 & Leonard D. White \\
1949 & V. O. Key \\
1950 & Stephen K. Bailey \\
1951 & John B. Herz \\
1952 & Samuel Lubbell \\
1953 & Clinton Rossiter \\
1954 & Bertram M. Gross \\
1955 & Jacobus ten Broek, \\
& Edward N. Barnhart, and \\
& Floyd W. Matson \\
1956 & Louis Hartz \\
1957 & James MacGregor Burns \\
1958 & Henry A. Kissinger \\
& Rexford G. Tugwell \\
1959 & Christian Bay \\
& James S. Coleman \\
1960 & Arnold Brecht \\
1961 & Richard Neustadt \\
1962 & Robert A. Dahl \\
1963 & Inis L. Claude \\
1964 & Raymond A. Bauer, \\
& Ithiel de Sola Pool, and \\
1965 & Anthony Lewis Dexter \\
& Robert E. Agger, \\
& Daniel Goldrich, and \\
& Bert E. Swanson \\
&
\end{tabular}

Title

The Web of Government

The Federalists: $A$ Study in Administrative History

Southern Politics in State and Nation

Congress Makes a Law

Political Realism and Political Idealism

The Future of American Politics

Seedtime of the Republic

The Legislative Struggle: A Study in Social Combat

Prejudice, War and the Constitution

The Liberal Tradition in America

The Lion and the Fox

Nuclear Weapons and Foreign Policy

The Democratic Roosevelt

The Structure of Freedom

Nigeria: Background to Nationalism

Political Theory

Presidential Power: The Politics of Leadership

Who Governs?

Power and International Relations

American Business and Public Policy

The Rulers and the Ruled
Published by

Macmillan Company

Macmillan Company

Yale University Press

Columbia University Press

University of Chicago Press

Harper \& Row

Brace \& Company

McGraw-Hill Book Company

University of California Press

Harcourt, Brace and Company

Harcourt, Brace and Company

Harper \& Row

Doubleday and Company

Stanford University Press

University of California

Princeton University Press

John Wiley and Sons, Inc.

Yale University Press

Random House

Atherton Press

John Wiley and Sons, Inc. 
Samuel J. Eldersveld Samuel H. Beer

Barrington Moore, Jr.

Duncan MacRae, Jr.

1969 Robert G. Dixon, Jr

1970 David Butler and

Donald E. Stokes

Ted Robert Gurr

David E. Apter

1973 Michael Brecher

1974 Robert A. Scalapino and

Chong-sik Lee

1975 Hugh Heclo

1976 Robert A. Alford

1977 Norman H. Nie,

Sidney Verba, and

John R. Petrocik

1978 Charles E. Lindblom

1979 Richard F. Fenno, Jr.

1980 Leslie H. Gelb with

Richard K. Betts

1981 John P. Gaventa

1982 Paul E. Peterson

1983 G. Bingham Powell

1984 George Th. Mavrogordatos

1985 Barry R. Posen

1986 Peter Katzenstein

1987 Philip E. Converse and

Roy Pierce

Peter Hall

1988 Robert Gilpin

1989 Larry Bartels

1990 Robert A. Dahl
Political Parties: A Behavioral Analysis

British Politics in the Collectivist Age

Social Origins of Dictatorship and Democracy

Parliament, Parties, and Society in France, 1946-1958

Democratic Representation

Political Change in Britain

Why Men Rebel

Choice and the Politics of Allocation

The Foreign Policy System of Israel: Setting, Images, Processes

Communism in Korea

Modern Social Politics in Britain and Sweden

Health Care Politics

The Changing American Voter

Politics and Markets

Home Style

The Irony of Vietnam

Power and Powerlessness: Quiescence and Rebellion in an Appalachian Valley

City Limits

Contemporary Democracies: Participation, Stability, and Violence

Stillborn Republic: Social Coalitions and Party

Strategies in Greece, 1922-1936

The Sources of Military Doctrine: France, Britain and Germany between the World Wars

Small States in World Markets: Industrial Policy in Europe

Political Representation in France

Governing the Economy

The Political Economy of International Relations

Presidential Primaries and the Dynamics of Public Choice

Democracy and Its Critics
Rand McNally

Alfred A. Knopf

Beacon Press

St. Martin's Press

Oxford University Press

St. Martin's Press

Princeton University Press

Yale University Press

Yale University Press

University of California Press

Yale University Press

University of Chicago Press

Harvard University Press

Basic Books

Little Brown

Brookings Institution

University of Illinois Press

University of Chicago Press

Harvard University Press

University of California Press

Cornell University Press

Cornell University Press

Harvard University Press

Oxford University Press

Princeton University Press

Princeton University Press

Yale University Press

\section{Paper and Article Awards}

\section{FRANKLIN L. BURDETTE PI SIGMA ALPHA AWARD}

This award is for the best paper presented at the previous Annual Meeting.

\begin{tabular}{|c|c|}
\hline Year & Author \\
\hline $\begin{array}{l}1964 \\
1965\end{array}$ & $\begin{array}{l}\text { James G. March } \\
\text { James B. Christoph }\end{array}$ \\
\hline $\begin{array}{l}1966 \\
1967\end{array}$ & $\begin{array}{l}\text { Samuel Huntington } \\
\text { Robert C. Tucker } \\
\text { Frederick Frey }\end{array}$ \\
\hline 1968 & Sidney Tarrow \\
\hline 1969 & Gerald H. Kramer \\
\hline 1970 & $\begin{array}{l}\text { Brian Fry and } \\
\text { Richard Winters }\end{array}$ \\
\hline 1971 & Daniel Ellsberg \\
\hline $\begin{array}{l}1972 \\
1973 \\
1974\end{array}$ & $\begin{array}{l}\text { Alexander George } \\
\text { No award given } \\
\text { William Zimmerman }\end{array}$ \\
\hline
\end{tabular}

Paper

An Individualistic Theory of Political Process

British Political Ideology Today: Consensus and Cleavage

Political Modernization: America vs. Europe

The Deradicalization of Marxist Movements

Socialization to National Identification: Turkish Peasants

Catch-all Political Parties in a Polarized Political System: An Empirical Analysis and Theoretical Critique

Short-Term Fluctuations in U.S. Voting Behavior, 1896-1964

The Politics of Redistribution

Escalating in a Quagmire

Multiple Advocacy in Making Foreign Policy

National-International Linkages in Yugoslavia: The
Affiliation

University of California, Irvine

Ohio State University

Harvard University

Princeton University

Massachusetts Institute of

Technology

Yale University

Yale University

Stanford University and Dartmouth College

Massachusetts Institute of Technology

Stanford University

University of Michigan 
Lloyd and Susanne Rudolph

1976

Richard F. Fenno

1977

Mary Cornelia Porter

1978

1979

1980

1981

1982

1983

\section{Jennifer Hochschild}

Kaare Strom

1984 Gary Miller and Terry Moe

1985 Jack L. Walker Michael Wallerstein

1986 Robert Axelrod

1987 James L. Gibson

1988 Ronald Rogowski

1989 George Rabinowitz, Stuart Elaine Macdonald, and Ola Listhaug

1990
Political Consequences of Openness

Authority and Power in Bureaucratic and Patrimonial Administration

Congressmen in Their Constituencies: An

Exploration

Rodriguez, the 'Poor' and the Burger Court: A Prudent Prognosis

Who Votes?

Pluralism and National Decline

Constants, Cycles, Trends and Persons in Presidential Governance: Carter's Troubles Reviewed

Toward a Normative Dynamic Model of Educational Equity

From Fundamental Law to the Supreme Law of the Land: A Reinterpretation of the Origin of Judicial

Law Review in the U.S.

Incrementalism, Pluralism and the Failure of School Desegregation

Minority Government and Majority Rule

The Positive Theory of Hierarchies

Three Modes of Political Mobilization

The Micro-Foundations of Corporatism: Formal Theory and Comparative Analysis

Modeling the Evolution of Norms

The Policy Consequences of Political Tolerance

Changing Exposure to Trade and the Development of Political Cleavages

New Players in an Old Game

The Notion of an Electoral Order: The Structure of Electoral Politics at the Accession of George Bush
University of Chicago

University of Rochester

Barat College

University of California, Berkeley

University of Maryland

University of Pittsburgh

National Science Foundation

California State University, Northridge

\section{Princeton University}

Stanford University

Michigan State University and Stanford University

University of Michigan

University of California, Los Angeles

University of Michigan

University of Houston

University of California, Los Angeles

University of North Carolina

University of Trondheim

Nuffield College

\section{HEINZ EULAU AWARD}

This award is for the best article published in The American Political Science Review in the previous year.

\begin{tabular}{clll} 
Year & Author & Article & Affiliation* \\
\hline 1988 & $\begin{array}{c}\text { Kenneth Shepsle and } \\
\text { Barry Weingast } \\
\text { James L. Gibson }\end{array}$ & The Institutional Foundations of Committee Power & $\begin{array}{c}\text { Harvard University and } \\
\text { Hoover Institution } \\
\text { University of Houston }\end{array}$ \\
1989 & $\begin{array}{c}\text { Political Intolerance and Political Repression During } \\
\text { the McCarthy Red Scare } \\
\text { Foreign Affairs and Issue Voting: Do Presidential } \\
\text { Candidates 'Waltz before a Blind Audience?' }\end{array}$ & $\begin{array}{c}\text { Duke University and } \\
\text { University of Minnesota }\end{array}$ \\
\hline
\end{tabular}

\section{Dissertation Awards}

\section{GABRIEL A. ALMOND AWARD}

This award is given each year for the best doctoral dissertation completed and accepted that year or the previous one in the field of comparative politics.

\begin{tabular}{cl} 
Year & Author \\
\hline 1977 & Kenneth Wald \\
1978 & Peter H. Lemieux \\
1979 & John T. S. Keeler \\
& Anne Louise Potter \\
1980 & Steven Jay Kelman
\end{tabular}

Dissertation

Patterns of English Voter Alignment Since 1885

The Liberal Party and British Political Change, $1955-74$

The Politics of Official Unionism in French Agriculture, 1958-1976

Political Institutions, Political Decay and the Argentine Crisis of 1930

Regulating Job Safety and Health: A Comparison of the U.S. Occupational Safety and Health Administration and the Swedish Worker Protection Board
Submitted by

Washington University

Massachusetts Institute of

Technology

Harvard University

Stanford University

Harvard University 
Kaare Strom David Pion-Berlin

Michael Loriaux

James Tong

1987 Frances Hagopian

1988 David Friedman

1989 Jeffrey Herbst

Sven Steinmo
State Formation and Absolutism in Comparative Perspective: Seventeenth-Century France and Mobutu Sese Seko's Zaire

The New Bourgeoisie and the Limits of Dependency: The Social and Political Impact of the Industry in Peru Since 1968

Austerity and Its Opposition: Italian Working Class Politics in the 1970s

Minority Government and Majority Rule

Ideas as Predictors: A Comparative Study of Coercion in Peru and Argentina

International Change and Political Adaptation: The French Overdraft Economy in the Seventies

Collective Violence in a Pre-modern Society: Rebellions and Banditry in the Ming Dynasty (1364-1644)

The Politics of Oligarchy: The Persistence of Traditional Elites in Contemporary Brazil

The Misunderstood Miracle: Politics and the Development of a Hybrid Economy in Japan

Policy Formulation and Implementation in Zimbabwe: Understanding State Autonomy and the Focus of Decision-Making

Taxes, Institutions and the Mobilization of Bias: The Political Economy of Taxation in Britain, Sweden and the United States

The Military Revolution and Political Change in Early Modern Europe
University of California, Berkeley

University of California, Los Angeles

Cornell University

Stanford University

University of Denver

Princeton University

University of Michigan

Massachusetts Institute of Technology

Massachusetts Institute of Technology

Yale University

University of California, Berkeley

University of Chicago

\section{WILLIAM ANDERSON AWARD}

This award is given each year for the best doctoral dissertation completed and accepted that year or the previous one in the field of state and local politics, federalism or intergovernmental relations.

\begin{tabular}{|c|c|c|c|}
\hline Year & Author & Dissertation & Submitted by \\
\hline 1977 & Alfred R. Light & $\begin{array}{l}\text { Intergovernmental Relations and Program Innovation: } \\
\text { The Institutionalized Perspectives of State } \\
\text { Administrator }\end{array}$ & University of North Carolina \\
\hline 1978 & No award given & & \\
\hline 1979 & Donald Kettl & $\begin{array}{l}\text { Managing Community Development in the New } \\
\text { Federalism }\end{array}$ & Yale University \\
\hline 1980 & Bruce Jacobs & The Political Economy of Organizational Change & Harvard University \\
\hline 1981 & No award given & & \\
\hline 1982 & Andrew B. Dunham & $\begin{array}{l}\text { Health and Politics: Cost Control and State } \\
\text { Certificate of Need Regulation }\end{array}$ & University of Chicago \\
\hline 1983 & No award given & & \\
\hline 1984 & Stephen C. Godek & $\begin{array}{l}\text { Determinants of Public Interest Cable Communication } \\
\text { Policies }\end{array}$ & University of Illinois at Chicago \\
\hline 1985 & No award given & & \\
\hline 1986 & Gregory R. Weiher & A Theory of Urban Political Boundaries & Washington University \\
\hline 1987 & Barry Rabe & $\begin{array}{l}\text { Functional Federalism and the Management of } \\
\text { Federal Programs in Health Care and Education }\end{array}$ & University of Chicago \\
\hline 1988 & No award given & & \\
\hline 1989 & John C. Drew & $\begin{array}{l}\text { Child Labor and Child Welfare: The Origins and } \\
\text { Uneven Development of the American Welfare } \\
\text { State }\end{array}$ & Cornell University \\
\hline 1990 & Jeffrey J. Anderson & $\begin{array}{l}\text { Territorial Networks of Interest in Britain and } \\
\text { Germany: Regions and the Politics of Economic } \\
\text { Decline }\end{array}$ & Yale University \\
\hline
\end{tabular}

\section{LEON M. BIRKHEAD AWARD}

This award was for the best doctoral dissertation completed and accepted during the last calendar year which made the greatest contribution toward the understanding of the traditions, institutions or methods of democracy or the forces threatening them.

\begin{tabular}{ll} 
Year & Author \\
\hline 1956 & Judith N. Shklar
\end{tabular}

Dissertation

Faith and Futility: Two Themes in Contemporary Political Theory
Submitted by

Radcliffe College 
1957 Richard Harmon McCleery

1958 Walter F. Murphy
Power, Communications and the Social Order: A Study of Prison Government

A Generation of Litigation: A Study in the Legislative Reactions to the School Desegregation Decisions
University of North Carolina

University of Chicago

\section{EDWARD S. CORWIN AWARD}

This award is for the best doctoral dissertation completed and accepted during that year or the previous year in the field of public law, broadly defined to include the judicial process, judicial behavior, judicial biography, courts, law, legal systems, the American constitutional system, civil liberties, or any other substantial area, or any work which deals in a significant fashion with a topic related to or having substantial impact on the American Constitution.

\begin{tabular}{|c|c|c|c|}
\hline Year & Author & Dissertation & Submitted by \\
\hline 1964 & David F. Hughes & Salmon P. Chase: Chief Justice & Centre College of Kentucky \\
\hline 1965 & John D. Sprague & $\begin{array}{l}\text { Voting Patterns on the United States Supreme Court: } \\
\text { Cases in Federalism, 1889-1959 }\end{array}$ & Washington University \\
\hline 1966 & William K. Muir, Jr. & Law and Attitude Change & Yale University \\
\hline 1967 & Richard Richardson & $\begin{array}{l}\text { A Study of the Judicial Process in Three U.S. Courts } \\
\text { of Appeals, 1956-1961 }\end{array}$ & Tulane University \\
\hline 1968 & No award given & & \\
\hline 1969 & James P. Levine & $\begin{array}{l}\text { The Bookseller and the Law of Obscenity: Toward an } \\
\text { Empirical Theory of Free Expression }\end{array}$ & Northwestern University \\
\hline 1970 & No award given & & \\
\hline 1971 & Douglas E. Rosenthal & $\begin{array}{l}\text { Client Participation in Professional Decision: The } \\
\text { Lawyer-Client Relationship in Personal Injury } \\
\text { Claims }\end{array}$ & Yale University \\
\hline 1972 & Walter G. Markham & $\begin{array}{l}\text { Draft Offenders in the Federal Courts: A Search for } \\
\text { the Social Correlates of Justices }\end{array}$ & University of Pennsylvania \\
\hline 1973 & Lief Hastings Carter & $\begin{array}{l}\text { The Limits of Order: Uncertainty and Adaptation in } \\
\text { a District Attorney's Office }\end{array}$ & University of California, Berkeley \\
\hline 1974 & James E. Radcliffe & $\begin{array}{l}\text { The Case-or-Controversy Provision-How Limited Is } \\
\text { the Political Role of the Federal Courts? }\end{array}$ & Pennsylvania State University \\
\hline 1975 & No award given & & \\
\hline 1976 & Thomas Uhlman & $\begin{array}{l}\text { Racial Justice: Black Judges and Defendants in the } \\
\text { Metro City Criminal Court, 1968-1974 }\end{array}$ & University of North Carolina \\
\hline 1977 & Milton Heumann & $\begin{array}{l}\text { Adapting to Plea Bargaining: The Experience of } \\
\text { Prosecutors, Judges and Defense Attorneys }\end{array}$ & Yale University \\
\hline 1978 & Philip Leon Dubois & $\begin{array}{l}\text { Judicial Elections in the States: Patterns and } \\
\text { Consequences }\end{array}$ & University of Wisconsin, Madison \\
\hline 1979 & Irving Frederick Lefberg & $\begin{array}{l}\text { Analyzing Judicial Change: The Uses of 'Systematic } \\
\text { Biography' in Anticipating the Court and Shaping } \\
\text { Its Future Policies }\end{array}$ & $\begin{array}{l}\text { Massachusetts Institute of } \\
\text { Technology }\end{array}$ \\
\hline & Harry N. Hirsch & $\begin{array}{l}\text { The Uses of Psychology in Judicial Biography: Felix } \\
\text { Frankfurter and the Ambiguities of Self-Image }\end{array}$ & Princeton University \\
\hline 1980 & Calvin Jillson & $\begin{array}{l}\text { Compromise and Critical Realignment in the } \\
\text { American Constitutional Convention of } 1787\end{array}$ & University of Maryland \\
\hline 1981 & Stanley Charles Brubaker & Benjamin Nathan Cardozo: An Intellectual Biography & University of Virginia \\
\hline 1982 & Timothy O'Neill & $\begin{array}{l}\text { The Politics of Equality: Litigational Politics and } \\
\text { Democratic Theory }\end{array}$ & University of California, Berkeley \\
\hline 1983 & Mark Silverstein & $\begin{array}{l}\text { Liberalism, Democracy, and the Court: Felix } \\
\text { Frankfurter, Hugo Black, and Constitutional } \\
\text { Decision-Making }\end{array}$ & Cornell University \\
\hline 1984 & Donald A. Downs & $\begin{array}{l}\text { Freedom, Community, and the First Amendment: } \\
\text { The Skokie Case and the Limits of Speech }\end{array}$ & University of California, Berkeley \\
\hline 1985 & Kim Lane Scheppele & $\begin{array}{l}\text { Legal Secrets: Common-Law Rules and the Social } \\
\text { Distribution of Knowledge }\end{array}$ & University of Chicago \\
\hline 1986 & Susan E. Lawrence & $\begin{array}{l}\text { The Poor in Court: The Legal Impact of Expanded } \\
\text { Access }\end{array}$ & Johns Hopkins University \\
\hline 1987 & H. W. Perry, Jr. & $\begin{array}{l}\text { Deciding to Decide: The Agenda-Setting Process in } \\
\text { the United States Supreme Court }\end{array}$ & University of Michigan \\
\hline 1988 & Graham Walker & $\begin{array}{l}\text { The Deep Structure of Contemporary Constitutional } \\
\text { Controversy: Morality, Skepticism and Augustine }\end{array}$ & University of Notre Dame \\
\hline 1989 & Mark Graber & $\begin{array}{l}\text { The Transformation of the Modern Constitutional } \\
\text { Defense of Free Speech }\end{array}$ & Yale University \\
\hline 1990 & James W. Tubbs & Roman Law Mind, Common Law Mind & Johns Hopkins University \\
\hline
\end{tabular}




\section{HAROLD D. LASSWELL AWARD}

This award is for the best doctoral dissertation completed and accepted during that year or the previous year in the field of policy studies (supported by the Policy Studies Organization).

\begin{tabular}{|c|c|c|c|}
\hline Year & Author & Dissertation & Submitted by \\
\hline 1984 & No award given & & \\
\hline 1985 & Bruce W. Jentleson & $\begin{array}{l}\text { Pipeline Politics: The Alliance and Domestic Politics } \\
\text { of American Economic Coercion Against the } \\
\text { Soviet Union }\end{array}$ & Cornell University \\
\hline 1986 & H. Jeffrey Leonard & $\begin{array}{l}\text { Pollution, Industrial Development, and Comparative } \\
\text { Advantage }\end{array}$ & Princeton University \\
\hline 1987 & James D. Savage & Balanced Budgets and American Politics & University of California, Berkeley \\
\hline 1988 & No award given & & \\
\hline 1989 & & $\begin{array}{l}\text { Technological Democracy: Bureaucracy and Citizenry } \\
\text { in the West German Energy Debate }\end{array}$ & $\begin{array}{l}\text { University of California, San } \\
\text { Diego }\end{array}$ \\
\hline & John Mark Hansen & $\begin{array}{l}\text { Creating a New Politics: The Evolution of an } \\
\text { Agricultural Policy Network in Congress, 1919-1980 }\end{array}$ & Yale University \\
\hline 1990 & Daniel J. Wirls & $\begin{array}{l}\text { Defense as Domestic Politics: National Security } \\
\text { Policy and Political Power in the 1980s }\end{array}$ & Cornell University \\
\hline
\end{tabular}

\section{J. KIMBROUGH OWEN AWARD}

This award was for the most significant doctoral dissertation completed and accepted during the past calendar year within the general field of state and local government, including intergovernmental relations and the modernization of state constitutions.

\begin{tabular}{|c|c|c|c|}
\hline Year & Author & Dissertation & Submitted by \\
\hline 1958 & Robert G. Scigliano & $\begin{array}{l}\text { Politics and the Judicial Process: The Michigan } \\
\text { One-Man Grand Jury }\end{array}$ & University of Chicago \\
\hline 1959 & Fred G. Burke & The Development of Local Governments in Uganda & Princeton University \\
\hline 1960 & Wilder Crane, Jr. & $\begin{array}{l}\text { The Legislative Struggle in Wisconsin: Decision- } \\
\text { Making in the } 1957 \text { Wisconsin Assembly }\end{array}$ & University of Wisconsin \\
\hline 1961 & Kent Jennings & $\begin{array}{l}\text { Political Statuses and Political Roles in Community } \\
\text { Decision Making }\end{array}$ & University of North Carolina \\
\hline 1962 & Theodore J. Lowi & $\begin{array}{l}\text { At the Pleasure of the Mayor: A Study of } \\
\text { Appointment Politics in New York City, 1989-1958 }\end{array}$ & Yale University \\
\hline
\end{tabular}

\section{HELEN DWIGHT REID AWARD}

This award is for the best doctoral dissertation completed and accepted during that year or the previous year in the field of international relations, law and politics.

\begin{tabular}{|c|c|c|}
\hline Year & Author & Dissertation \\
\hline 1966 & William Zimmerman & $\begin{array}{l}\text { Soviet Perspectives in the International System, } \\
1956-1964\end{array}$ \\
\hline 1967 & No award given & \\
\hline 1968 & Perry Smith & $\begin{array}{l}\text { Wartime Planning for Postwar Contingencies: The } \\
\text { Army Air Force Example, 1943-1946 }\end{array}$ \\
\hline 1969 & No award given & \\
\hline 1970 & Francis Seth Singleton & The African States and the Congo Affair, 1960-65 \\
\hline 1971 & No award given & \\
\hline 1972 & Stuart A. Bremer & $\begin{array}{l}\text { National and International Systems: A Computer } \\
\text { Analysis }\end{array}$ \\
\hline 1973 & Richard Smoke & $\begin{array}{l}\text { Toward the Control of Escalation: An Historical } \\
\text { Analysis }\end{array}$ \\
\hline 1974 & Peter J. Katzenstein & Disjointed Partners: Austria and Germany Since 1815 \\
\hline 1975 & No award given & \\
\hline 1976 & No award given & \\
\hline 1977 & Jack Steven Levy & $\begin{array}{l}\text { Military Power, Alliances, and Technology: An } \\
\text { Analysis of Some Structural Determinants of } \\
\text { International War Among the Great Powers }\end{array}$ \\
\hline 1978 & Thomas J. Biersteker & $\begin{array}{l}\text { Multinational Investments in Underdeveloped } \\
\text { Countries: An Evaluation of Contending } \\
\text { Perspectives }\end{array}$ \\
\hline 1979 & Stephen Michael Meyer & Probing the Causes of Nuclear Proliferation \\
\hline 1980 & James P. Bennett & $\begin{array}{l}\text { Perpetuating Failure: Security Practices and System } \\
\text { Transformation of Southern Pacific Transnational } \\
\text { Politics } 1830-1905\end{array}$ \\
\hline
\end{tabular}

Submitted by

Columbia University

Columbia University

Yale University

Michigan State University

Massachusetts Institute of

Technology

Harvard University

University of Wisconsin, Madison

Massachusetts Institute of Technology

University of Michigan

Massachusetts Institute of Technology 


\begin{tabular}{ll}
1981 & Margaret Scranton \\
1982 & Timothy Lomperis \\
1983 & Deborah Larson \\
1984 & Scott Sagan \\
1985 & Wayne A. Edisis \\
1986 & Michael Mastanduno \\
1987 & Douglas J. Macdonald \\
1988 & Aaron L. Friedberg \\
1989 & Yossi Shain \\
1990 & Steven Weber \\
\hline
\end{tabular}

Changing U.S. Foreign Policy: Negotiating New Panama Canal Treaties, 1958-1978

A Conceptual Framework for Deriving the "Lessons of History": The U.S. Involvement in Viet Nam (1960-1975) as a Case Study

Belief and Inference: The Origins of American Leaders' Cold War Ideology

Deterrence and Decision: An Historical Critique of Modern Deterrence Theory

The Hidder Agenda: Negotiations for the Generalized System of Preferences

Between Economics and National Security: The Western Politics of East-West Trade

Adventures in Chaos: Reformism in American Foreign Policy

Change, Assessment and Adaptation: Britain and the Experience of Relative Decline, 1895-1905

In Search of Loyalty and Recognition: The Political Activities of Exiles

Cooperation and Discord in Security Relationships: Toward a Theory of U.S.-Soviet Arms Control
University of Pittsburgh

Duke University

Stanford University

Harvard University

Brandeis University

Princeton University

Columbia University

Harvard University

Yale University

Stanford University

\section{E. E. SCHATTSCHNEIDER AWARD}

This award is for the best doctoral dissertation completed and accepted during that year or the previous year in the field of American government.

\begin{tabular}{|c|c|c|c|}
\hline Year & Author & Dissertation & Submitted by \\
\hline 1972 & Paul M. Sniderman & $\begin{array}{l}\text { Personality and Democratic Politics: Correlates of } \\
\text { Self-Esteem }\end{array}$ & University of California, Berkeley \\
\hline 1973 & Michael Jay Robinson & $\begin{array}{l}\text { Public Affairs Television and the Growth of Political } \\
\text { Malaise: The Case of the Selling of the Pentagon }\end{array}$ & University of Michigan \\
\hline 1974 & Lawrence E. McCray & $\begin{array}{l}\text { The Politics of Regulation: Multi-firm Trade } \\
\text { Associations in Telecommunications Policy Making }\end{array}$ & $\begin{array}{l}\text { Massachusetts Institute of } \\
\text { Technology }\end{array}$ \\
\hline 1975 & Dall Worthington Forsythe & $\begin{array}{l}\text { Taxation and Regime Change in America, 1781-1833: } \\
\text { A Taxonomy of Political Events }\end{array}$ & Columbia University \\
\hline 1976 & W. Lance Bennett & The Political Mind and the Political Environment & Yale University \\
\hline 1977 & Kristi Anderson & $\begin{array}{l}\text { How Realignments Happen: Mobilization and the } \\
\text { Creation of a Democratic Majority, 1928-1936 }\end{array}$ & University of Chicago \\
\hline 1978 & Michael T. Hayes & $\begin{array}{l}\text { An Economic Theory of Interest Groups and Public } \\
\text { Policy }\end{array}$ & Indiana University \\
\hline 1979 & Rodger Robert Huckfeldt & $\begin{array}{l}\text { Political Behavior and the Social Context of Urban } \\
\text { Neighborhoods }\end{array}$ & Washington University \\
\hline 1980 & No award given & & \\
\hline 1981 & Byron E. Shafer & $\begin{array}{l}\text { The Party Reformed: Reform Politics in the } \\
\text { Democratic Party, 1968-1972 }\end{array}$ & University of California, Berkeley \\
\hline 1982 & Paul Light & $\begin{array}{l}\text { The President's Agenda: Domestic Policy Choice } \\
\text { from Kennedy to Carter }\end{array}$ & University of Michigan \\
\hline 1983 & Thomas W. Wolf & $\begin{array}{l}\text { Congressional Sea Change: Conflict and } \\
\text { Organizational Accommodation in the House of } \\
\text { Representatives 1878-1921 }\end{array}$ & $\begin{array}{l}\text { Massachusetts Institute of } \\
\text { Technology }\end{array}$ \\
\hline 1984 & Larry M. Bartels & $\begin{array}{l}\text { Presidential Primaries and the Dynamics of Public } \\
\text { Choice }\end{array}$ & University of California, Berkeley \\
\hline 1985 & John Zaller & The Role of Elites in Shaping Public Opinion & University of California, Berkeley \\
\hline 1986 & Mark Alex Peterson & $\begin{array}{l}\text { Domestic Policy and Legislative Decision-Making: } \\
\text { Congressional Responses to Presidential Initiatives }\end{array}$ & University of Michigan \\
\hline 1987 & Lawrence Rothenberg & $\begin{array}{l}\text { The Politics and Economics of Regulation and } \\
\text { Deregulation: Motor Freight Policy at the Interstate } \\
\text { Commerce Commission }\end{array}$ & Stanford University \\
\hline 1988 & Mark C. Westlye & Dynamics of U.S. Senate Elections & University of California, Berkeley \\
\hline 1989 & Victoria Hattam & $\begin{array}{l}\text { Unions and Politics: The Courts and American } \\
\text { Labor: } 1806-1896\end{array}$ & $\begin{array}{l}\text { Massachusetts Institute of } \\
\text { Technology }\end{array}$ \\
\hline 1990 & Laura Stoker & Morality and the Study of Political Behavior & University of Michigan \\
\hline
\end{tabular}




\section{LEO STRAUSS AWARD}

This award is for the best doctoral dissertation completed and accepted during that year or the previous year in the field of political philosophy.

\begin{tabular}{|c|c|c|c|}
\hline Year & Author & Dissertation & Submitted by \\
\hline $\begin{array}{l}1975 \\
1976\end{array}$ & $\begin{array}{l}\text { Delba Winthrop } \\
\text { Dennis Bremman }\end{array}$ & $\begin{array}{l}\text { Aristotle: Democracy in Political Science } \\
\text { Hobbes' Original Political Science: Observed or } \\
\text { Postulated? }\end{array}$ & $\begin{array}{l}\text { Harvard University } \\
\text { University of Notre Dame }\end{array}$ \\
\hline 1977 & Mary L. Pollingue & A Community on Plato's Phaedrus & University of Chicago \\
\hline 1978 & Richard Johnson & $\begin{array}{l}\text { Strategy and Enlightenment: A Critical Study of the } \\
\text { 'Marxisms' of Jean-Paul Sartre and Louis Althusser }\end{array}$ & Yale University \\
\hline 1979 & Arthur M. Melzer & $\begin{array}{l}\text { The Happiness of the Ordinary Man: Rousseau on } \\
\text { Virtue and Goodness }\end{array}$ & Harvard University \\
\hline 1980 & $\begin{array}{l}\text { Joel Benjamin Schwartz } \\
\text { Joseph V. Brogan }\end{array}$ & $\begin{array}{l}\text { The Sexual Politics of Jean-Jacques Rousseau } \\
\text { The New Rationalists: An Inquiry into the Philosophy } \\
\text { of Positive Political Theory }\end{array}$ & $\begin{array}{l}\text { Harvard University } \\
\text { University of Notre Dame }\end{array}$ \\
\hline 1981 & James Leake & Tacitus' Teaching and the Decline of Liberty at Rome & Boston College \\
\hline 1982 & Michael A. Gillespie & $\begin{array}{l}\text { Hegel, Heidegger, and the Ontological Ground of } \\
\text { History }\end{array}$ & University of Chicago \\
\hline 1983 & Wayne Ambler & Aristotle on the Naturalness of the City & Boston College \\
\hline 1984 & Asher Horowitz & $\begin{array}{l}\text { Nature and History in the Social and Political } \\
\text { Thought of Jean-Jacques Rousseau }\end{array}$ & University of Toronto \\
\hline 1985 & $\begin{array}{l}\text { Ruth Grant } \\
\text { Ian Shapiro }\end{array}$ & $\begin{array}{l}\text { John Locke's Liberalism } \\
\text { Individual Rights in Modern Liberal Thought: A } \\
\text { Realist Account }\end{array}$ & $\begin{array}{l}\text { University of Chicago } \\
\text { Yale University }\end{array}$ \\
\hline 1986 & Steven Forde & $\begin{array}{l}\text { Thucydides' Alcibiades: A Case Study of the Place of } \\
\text { Alcibiades in Thucydides' History }\end{array}$ & University of Toronto \\
\hline 1987 & Richard C. Sinopoli & $\begin{array}{l}\text { Liberalism, Republicanism and the Constitution: } \\
\text { American Citizenship Viewed from the Founding }\end{array}$ & New York University \\
\hline 1988 & Peter Berkowitz & The Foundations of Nietzsche's Political Philosophy & Yale University \\
\hline 1989 & Tai-Shuenn Yang & $\begin{array}{l}\text { Property Rights and Constitutional Order in Imperial } \\
\text { China }\end{array}$ & Indiana University \\
\hline 1990 & Alan Houston & $\begin{array}{l}\text { Algernon Sidney and the Republican Heritage in } \\
\text { England and America }\end{array}$ & Harvard University \\
\hline
\end{tabular}

\section{LEONARD D. WHITE AWARD}

This award is for the best doctoral dissertation completed in that year or the previous year in the general field of public administration, including broadly related problems of policy formation and administrative theory.

\begin{tabular}{|c|c|c|c|}
\hline Year & Author & Dissertation & Submitted by \\
\hline 1959 & Dean E. Mann & $\begin{array}{l}\text { The Administration of Water Resources in the State } \\
\text { of Arizona }\end{array}$ & University of California, Berkeley \\
\hline 1960 & Daniel J. Elazar & $\begin{array}{l}\text { Intergovernmental Relations in Nineteenth Century } \\
\text { American Federalism }\end{array}$ & University of Chicago \\
\hline 1961 & Laurin Henry & Presidential Transitions & University of Chicago \\
\hline 1962 & Simon D. Perry & $\begin{array}{l}\text { The Conflict of Expectations and Roles in Policy } \\
\text { Science Behavior }\end{array}$ & Michigan State University \\
\hline $\begin{array}{l}1963 \\
1964 \\
1965 \\
1966\end{array}$ & $\begin{array}{l}\text { Karl A. Hochschwender } \\
\text { No award given } \\
\text { No award given } \\
\text { No award given }\end{array}$ & The Politics of Civil Service Reform in West Germany & Yale University \\
\hline 1967 & John P. Crecine & $\begin{array}{l}\text { A Computer Simulation Model of Municipal Resource } \\
\text { Allocation }\end{array}$ & Carnegie Institute of Technology \\
\hline 1968 & Clyde D. McKee, Jr. & $\begin{array}{l}\text { The Politics of Council-Manager Forms Having and } \\
\text { Not Having the Partisan Election }\end{array}$ & University of Connecticut \\
\hline 1969 & Russell Murphy & $\begin{array}{l}\text { Policy Innovation and Political Strategy in an } \\
\text { American City: The Formative Years of New } \\
\text { Haven, Connecticut's Anti-Poverty Project }\end{array}$ & Yale University \\
\hline 1970 & Gary W. Wynia & $\begin{array}{l}\text { Policy and Bureaucracy in Central America: A } \\
\text { Comparative Study }\end{array}$ & University of Wisconsin, Madison \\
\hline 1971 & Larry B. Hill & $\begin{array}{l}\text { The International Transfer of Political Institutions: } \\
\text { A Behavioral Analysis of the New Zealand } \\
\text { Ombudsman }\end{array}$ & Tulane University \\
\hline \multirow[t]{2}{*}{1972} & Ezra N. Suleiman & $\begin{array}{l}\text { Administration, Politics and the Higher Civil Service } \\
\text { in France }\end{array}$ & Columbia University \\
\hline & Jessica Wolf & Toward a Model of Inter-organizational Behavior: & Yale University \\
\hline
\end{tabular}


1973 Douglas T. Yates, Jr.

1974 James Norris Danziger

1975 Arnold Kanter

Harry Kranz

1976 Robert Rich

1977 George Woodrow Downs, Jr.

1978 Frederic Allan Bergerson

1979 Daniel S. Metlay

1980 John Edward Chubb

1981 J. Serge Taylor

1982 Judith Gruber

1983 John Swain

1984 Ronald B. Hoskins

1985 Donald W. Chisholm

1986 Elisabeth Hollister Sims

1987 John DiIulio, Jr.

1988 Chris C. Demchak

1989 Roy T. Meyers

1990 Shui Yan Tang
Two Case Studies in France

Neighborhood Democracy: the Politics and Impacts of Decentralization

Budget-Making and Expenditure Variations in English County Boroughs

The Organizational Politics of National Security Policy: A Budgetary Perspective

A More Representative Bureaucracy: The Adequacy and Disability of Minority and Female Population Parity in Public Employment

An Investigation of Information Gathering and Handling in Seven Federal Bureaucracies: A Case Study of the Continuous National Survey

Bureaucracy, Innovation and Public Policy

The Army Gets an Air Force: The Tactics and Process of Insurgent Bureaucratic Politics

Error Correction in Bureaucracy

Interest Groups and the Bureaucracy: the Politics of Energy

Environmentalists in the Bureaucracy: Environmental Impact Analysis in the Forest Service and the Army Corps of Engineers

Democracy versus Bureaucracy: The Problem of Democratic Control

An Evaluation of the Public Choice Approach to Structuring Local Government in Metropolitan Areas

Within-Year Appropriations Changes in Georgia State Government: The Implications for Budget Theory

Informal Organization and the Problem of Coordination

Rural Development and Public Policy: Agricultural Institutions and Technological Change in the Indian and Pakistani Punjab

Governing Prisons: A Comparative Study of Correctional Management

War, Technological Complexity, and the U.S. Army

Microbudgetary Strategies and Outcomes

Institutions and Collective Action in Irrigation Systems
Yale University

Stanford University

Yale University

American University

University of Chicago

University of Michigan

Vanderbilt University

University of California, Berkeley

University of Minnesota

University of California, Berkeley

Yale University

Northern Illinois University

University of Georgia

University of California, Berkeley

University of California, Berkeley

Harvard University

University of California, Berkeley University of Michigan

Indiana University

\section{APSA Publications List}

\footnotetext{
* Available from Customer Services Department, University Microfilms, 300 North Zeeb Road, Ann Arbor, Michigan 48106; (800) 521-0600.
}

\section{PERIODICALS}

The American Political Science Review. The leading quarterly journal of scholarly articles and book reviews in political science. Included in APSA membership. Back issues: $\$ 20$ per copy, add $\$ 1.50$ postage or $\$ 3$ overseas; $\$ 80$ per volume, add $\$ 5$ postage or $\$ 10$ overseas.

PS: Political Science \& Politics. Quarterly journal of Association news and lively articles of political analysis. $P S$ is the best single source of information on professional opportunities. Included in
APSA membership. Back issues: $\$ 5$ per copy, add $\$ 1.50$ postage or $\$ 3$ overseas; $\$ 20$ per volume, add $\$ 5$ postage or $\$ 10$ overseas (\$6 for the spring issue which contains the preliminary program, add $\$ 1.50$ postage or $\$ 3$ overseas).

The Political Science Teacher. Stimulating quarterly magazine on education, curriculum, and teaching. Distributed to U.S. individual members only. Fall 1990 issue to be last separate issue of The Teacher. Starting March 1991 The

Teacher will be incorporated into $P S$.

this Constitution: A Bicentennial Chronicle. Quarterly magazine with articles on the Bicentennial. The magazine is supported by a grant from the National Endowment for the Humanities. It is a joint publication of the American Historical Association and the American Political Science Association. No longer in print as a subscription. Back issues available at \$4 each, issues \#13-17: \$6 each issue \#18. Bulk prices available. Add
$\$ 1$ postage each copy.

\section{DIRECTORIES}

APSA Biographical Directory. Names, addresses, current position, institutional affiliation, highest degree, fields of specialization, and honors and publications of APSA individual members. Index includes listings of women, Black and Hispanic members, a geographical listing, and a listing of members by fields of interest. \$25, APSA members; $\$ 35$, nonmembers (+ $\$ 2.50$ postage). 1988 .

Directory of Black Americans in Political Science. Lists over 400 Black American political scientists by name, address, phone, degrees, and fields of specialization. Indexed by field of academic specialization and research interests. \$10, APSA members; $\$ 15$, nonmembers (+\$2.50 postage). 2nd edition, 1988.

Directory of Undergraduate Political Science Faculty, 1990. Available March 